\title{
Bridging the K-12/Postsecondary Divide With a Coherent K-16 System
}

Consortium for Policy Research in Education

Follow this and additional works at: https://repository.upenn.edu/cpre_policybriefs

Part of the Curriculum and Instruction Commons, Educational Assessment, Evaluation, and Research Commons, and the Education Policy Commons

\section{Recommended Citation}

Consortium for Policy Research in Education. (2000). Bridging the K-12/Postsecondary Divide With a Coherent K-16 System. CPRE Policy Briefs.

Retrieved from https://repository.upenn.edu/cpre_policybriefs/19

View on the CPRE website.

This paper is posted at ScholarlyCommons. https://repository.upenn.edu/cpre_policybriefs/19

For more information, please contact repository@pobox.upenn.edu. 


\title{
Bridging the K-12/Postsecondary Divide With a Coherent K-16 System
}

\begin{abstract}
This Policy Brief originates from a conference held at Stanford University titled, "Education Reform into the Millennium: The State Legislatures' Role in Building a Consensus for Systemic Change." The conference, which was held from September 30 to October 2, 1999, was sponsored by the National Conference of State Legislatures, the Consortium for Policy Research in Education, the Education Commission of the States, and the Institute for Educational Leadership. It was funded by the Office of Educational Research and Improvement of the U.S. Department of Education. Fifty-three legislators and representatives from 15 states attended the conference. The presenters included an array of educators, scholars, and policy analysts.
\end{abstract}

American education has long been characterized by a profound disjuncture between $\mathrm{K}-12$ and postsecondary education-two systems that often act independently and at crosspurposes from one another. This is hardly a new insight. In 1969, Michael Usdan, currently the president of the Institute for Educational Leadership, and others published Education and State Politics, which scrutinized the lack of connection between segments of the educational system. And in 1985, Harold Hodgkinson, formerly of the Institute for Educational Leadership, published All One System, in which he argued that the nation's graduate schools were dependent in part on the quality of its kindergarten programs.

In the past, discussions about the unhealthy divisions between the two educational systems mostly fell on deaf ears. But recently there has been a heightened recognition on the part of policymakers, educators, and legislators as to just how inefficient and even harmful these gaps have been. Over a dozen states and at least 35 communities have started or are planning to start cross-system collaborations.

\section{Disciplines}

Curriculum and Instruction | Educational Assessment, Evaluation, and Research | Education Policy

\section{Comments}

View on the CPRE website. 


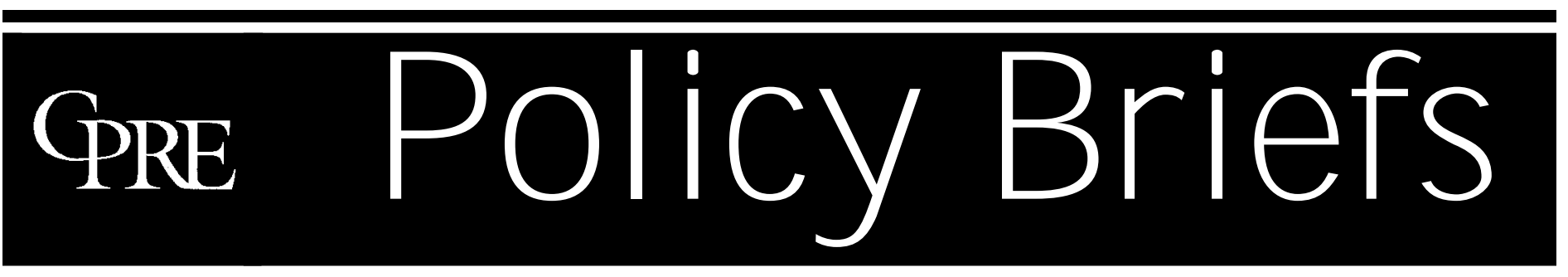

Reporting on issues in education reform

Graduate School of Education - $\quad$ University of Pennsylvania $\quad$ RB-31-June2000

\section{Bridging the K-12/ Postsecondary Divide With a Coherent K-16 System}

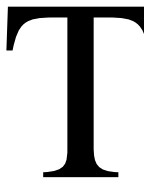

his Policy Brief originates from a conference held at Stanford University titled, "Education Reform into the Millennium: The State LegislaConic Change." Role in Building a Consensus for Systemic Change." The conference, which was held from September 30 to October 2, 1999, was sponsored by the National Conference of State Legislatures, the Consortium for Policy Research in Education, the Education Commission of the States, and the Institute for Educational Leadership. It was funded by the Office of Educational Research and Improvement of the U.S. Department of Education. Fifty-three legislators and representatives from 15 states attended the conference. The presenters included an array of educators, scholars, and policy analysts.

American education has long been characterized by a profound disjuncture between K-12 and postsecondary education - two systems that often act independently and at crosspurposes from one another. This is hardly a new insight. In 1969, Michael Usdan, currently the president of the Institute for Educational Leadership, and others published Education and State Politics, which scrutinized the lack of connection between segments of the educational system. ${ }^{1}$ And in 1985,
Harold Hodgkinson, formerly of the Institute for Educational Leadership, published All One System, in which he argued that the nation's graduate schools were dependent in part on the quality of its kindergarten programs. ${ }^{2}$

In the past, discussions about the unhealthy divisions between the two educational systems mostly fell on deaf ears. But recently there has been a heightened recognition on the part of policymakers, educators, and legislators as to just how inefficient and even harmful these gaps have been. Over a dozen states and at least 35 communities have started or are planning to start cross-system collaborations.

Their actions have been inspired in part by the increase in the percent and number of students attending postsecondary institutions; over 72 percent of high school graduates now enroll in some kind of postsecondary institution. ${ }^{3}$ Indeed, attendance at a technical institute, community college, or university is becoming essential for those who want rewarding and well-compensated careers. This is not to suggest that all students need to attend a postsecondary institution —-indeed, some may better fulfill their aspirations elsewhere. But as Stanford professor Michael Kirst, Education Trust Director Kati

The Consortium for Policy Research in Education (CPRE) studies alternative approaches to education reform in order to determine how state and local policies can promote student learning. Currently, CPRE's work is focusing on accountability policies, efforts to build capacity at various levels within the education system, methods of allocating resources and compensating teachers, and governance changes like charters and mayoral takeover. The results of this research are shared with policymakers, educators, and other interested individuals and organizations in order to promote improvements in policy design and implementation. CPRE is supported by the National Institute on Educational Governance, Finance, Policymaking, and Management, Office of Educational Research and Improvement, U.S. Department of Education. 
Haycock, and others stated at the "Education Reform into the Millennium" conference, far too many students-especially those who come from economically disadvantaged households-aspire to go to college but have little information regarding what the admissions and placement policies of postsecondary institutions require. Nor do they understand what knowledge and skills they will need to be successful in postsecondary institutions. This is a threat to a democratic society. Uninformed students are likely to miss taking important academic courses, almost ensuring that they will be inadequately prepared for postsecondary work. Many are not motivated to do the academic work that would prepare them. These problems are compounded by the weak education students often receive at schools staffed with underqualified teachers.

Currently, K-12 and postsecondary institutions move in different orbits, upholding different sets of standards regarding what students should know and be able to do. Aligning these different standards and then providing all students hoping to attend postsecondary institutions with the information and academic skills they need to succeed would represent enormous leaps forward, especially during this time of declining affirmative action admissions. On one hand, the college-bound would be much better prepared. On the other hand, students considering options other than college might with good counseling realize early on that their aspirations do not necessarily require a college education. And, if they attend improved high schools with better teaching aligned to more rigorous standards, they will be in a better position to acquire a technical training or to enter the job market directly.

This Policy Brief looks at some of the primary causes of the disjunctures between the K-12 and postsecondary systems and the problems that have resulted for students, teachers, and postsecondary administrators and faculty. It then looks at some ways this gap can be addressed by "institutionalizing" a K-16 perspective and improving teaching to meet more demanding K-16 standards.

\section{The Development of Two Separate-and Often Inefficient- Systems}

As Kirst discussed at the Fall 1999 conference, the separation between the K-12 and postsecondary education systems is extremely sharp in the United States-more than in the rest of the world. In England, for example, the universities have long controlled the secondary school curriculum, which essentially prepares and sorts out students for university admission. England, which now sends a similar percentage of students to postsecondary institutions as the United States does, uses two secondary school graduation exams that are aligned with K-16 standards. In the United States, the massive K-12 system was constructed first, after which the postsecondary system was expanded independently to accommodate the majority of high school graduates. The two systems subsequently developed separate and typically different structures for such tasks as establishing academic standards, assessing the performance of students and faculty, organizing curricula and programs, and recruiting and compensating faculty. Historically, the two systems have had a tentative and sometimes uncomfortable relationship - a trend that continues to this day.

In recent years, for example, states have developed K-12 academic standards and assessments in order to raise the quality of K-12 education. Yet they have, with few exceptions, developed these standards and assessments with little input from postsecondary faculty. Likewise, postsecondary institutions have established admissions and placement standards without consulting educators and policymakers in the $\mathrm{K}-12$ arena. The result is a misalignment between the two systems, which means that even students who have acquired the skills and knowledge required by the standards may not be well-prepared for postsecondary work. It also means that educators/advisors at each level are not able to teach/assist students as well as they would if they understood the expectations of the other system.

\section{About CPRE Policy Briefs}

CPRE Policy Briefs are published by the Consortium for Policy Research in Education (CPRE). The research reported in this issue was supported by a subcontract to CPRE from the National Conference of State Legislatures (grant no. R215U980024 from the Office of Educational Research and Improvement, U.S. Department of Education). The views expressed in this publication are those of its authors and are not necessarily shared by the Office of Educational Research and Improvement, the U.S. Department of Education, the National Conference of State Legislatures, CPRE, or its institutional members. 
Indeed, only Advanced Placement courses, for which high school students can gain college credit, are relatively wellaligned with university coursework. But Advanced Placement courses are intended for the "top tier" of students who will attend four-year colleges or universities. They have little relevance to the majority of students who may want to attend postsecondary institutions.

The existing divide between K-12 and postsecondary education causes a number of significant problems: conflicting standards for students, unequal opportunities for different groups of students, placement exam confusion and intensive remediation, high college drop-out rates, and finger-pointing.

Conflicting standards for students. Virtually every state in the nation now has academic standards for K-12 education, and the vast majority of the states are in the process of developing assessments aligned to these standards. However, the standards are almost always self-contained within the K12 universe and have little connection with the admissions, placement, and academic requirements of postsecondary institutions. Therefore, students might find themselves in the paradoxical situation of meeting demanding high school graduation standards yet still being prepared inadequately for postsecondary academic work. They also might pass an exitlevel exam in high school and still score poorly on placement exams. Eventually, students will become resentful at having to take standards-based assessments that they see as irrelevant to postsecondary admissions or, for that matter, to getting good jobs (employers generally do not ask to see test score results). This has already begun to occur. In Massachusetts and Michigan, for instance, some high school students have boycotted the exams.

Most colleges and universities rely on the American College Test (ACT) and the Scholastic Achievement Test (SAT) to gauge the qualifications of students. But the ACT and SAT are not aligned with the new K-12 standards. Furthermore, both the ACT and SAT measure writing skills with multiple choice items, meaning that even some students with high scores may nevertheless have trouble with written English placement exams.

Unequal opportunities for different groups of students to succeed in postsecondary education. A lack of clear signals regarding postsecondary admissions and placement exams is particularly harmful to minority and immigrant students, as well as to those from economically disadvantaged families. Middle and upper class students have formal and informal means of acquiring information about the requirements for educational opportunities after high school; many attend schools with intensive college and career counseling programs and have siblings and parents who attended college. Less fortunate students, however, must figure out on their own the pathways to entering postsecondary institutions. Often, for instance, they think that getting good grades in high school is the key to postsecondary success, not realizing that much depends on the results of admissions and placement tests of which neither they nor their high school teachers have knowledge.

Placement exam confusion and intensive remediation. In 1995, nearly all public two-year institutions and 81 percent of public four-year institutions offered remedial courses; that fall, 29 percent of all first-time students enrolled in at least one remedial reading, writing, or mathematics course. ${ }^{4}$ In the spring of 1998, the 22-campus California State University System reported that a record 57 percent of freshmen had to take remedial English; 54 percent were enrolled in remedial math. ${ }^{5}$

Spokespersons for postsecondary institutions and policymakers often claim that a lack of academic rigor in high school is responsible for high rates of remediation. Indeed, a Massachusetts plan has been launched that would make school districts pay for the remediation of first-year postsecondary students; while in other states, universities are redirecting students to community colleges for remedial work.

In truth, though, the high rates of remediation likely have as much to do with the disjunctures in the $\mathrm{K}-16$ system as with shortcomings in high school education. Colleges and universities, for instance, administer a plethora of placement exams; almost all designed without regard to K-12 standards and curricula. In the southeast, for example, there are nearly 125 combinations of 75 different placement exams devised by college and university academic departments independent of school districts. It is hardly surprising, then, that entering first-year students have little information about placement exams, if any at all, and that so many of them score poorly and end up in remedial courses.

High college drop-out rates. In addition to intensive remediation, many students drop out of college altogetheras many as 50 percent in some state university systems according to Kirst. Some of these students may very well have benefited from two-year technical programs that would have prepared them for jobs. Better counseling and information in their high school years might have steered them in this direction, sparing them and the public the dollars misspent on fouryear programs. 
Finger-pointing. Speaking of the deep disjunctures that currently exist within the K-16 system, Usdan told the legislators attending the Fall 1999 conference, "Basically we've passed the buck and created a system that allows for it." Because there is not an integrated accountability system for the two systems, postsecondary faculties blame high schools for sending them poorly prepared students; high school administrators blame colleges for not doing a better job preparing teachers; high school teachers blame middle and elementary schools for not better preparing students for secondary school; students and their parents often cite a lack of information about what is required for postsecondary admissions and course placement. Everyone is to blame; no one is responsible.

\section{Moving Toward a K-16 System: Institutionalizing the Perspective}

In all but a few states, such as Georgia and Maryland, there is no legislative or advisory body responsible for K-16 issues. The establishment of such a unified body is an important first step toward addressing the coordination and alignment problems described above. As Jerry Hayward, Co-Director of Policy Analysis for California Education, said in his presen- tation to the conference audience, "Attempts at collaboration usually fail against segmentation unless there is some kind of broad-based institutional effort."

In a paper presented at the "Education Reform into the Millennium" conference, David Conley, Executive Director of Proficiency-Based Admission Standards System in the Oregon University System, offered recommendations for beginning K-16 action (see Sidebar 1). In many cases, ad hoc commissions are the best tools with which to begin a study of K-16 issues, asserted Conley. Such groups can draw leadership from outside of the two systems, providing fresh perspectives and setting the stage for cross-system actions. ${ }^{6}$ But if they are to hold any sway, he continued, they likely would need the authority to induce the K-12 and postsecondary systems to enter into discussion. Of course, just what kind of deliberative body is formed to consider K16 issues, and the amount of authority such a body will be granted, are likely to vary greatly from state to state.

Currently, most postsecondary institutions pay little attention to the assessments that an increasing number of states are requiring of their high school students. In California, for instance, postsecondary institutions do not ask for students' scores on the state's STAR (Standardized Testing and Re-

\section{Sidebar 1 David Conley's Recommendations for Beginning K-16 Action}

- Reexamine the traditional separation of educational governance into a K-12 governing board and one or more higher education boards.

- Allow for joint budgeting in certain areas so projects that cut across system boundaries can be funded.

- To begin the alignment process, consider forming ad hoc commissions that draw on leadership from outside the two systems.

- Encourage the staffs of the two education agencies to work together so they can begin to break down the poor communication that has long existed between high school teachers and postsecondary faculty.

- Begin the effort to align K-12 assessment systems with postsecondary admissions and placement exams.

- Refuse to mask the complex problems of poorly performing schools and institutions behind policies that legitimize their inflationary grading systems.

- Consider requiring postsecondary institutions to provide assistance to any student they admit who appears unable to do university-level work.

- Design incentive and sanction systems that encourage K-12 and postsecondary institutions to interact for their own benefits.

- Authorize a national clearinghouse on the use of state standards and assessment for postsecondary admission such as the type being developed by the American Association of Universities. This would give states a way to determine if what they are doing with K-12 standards is linked to postsecondary admission and success. 
porting) program or Golden State Exams (the state's series of end-of-course exams), even though these assessments are used by parents, policymakers, and educators to gauge how well students and schools are performing. Instead, postsecondary institutions tend to rely on SAT and ACT scores, which are not even required for students who do not plan to attend four-year institutions. As Kirst has argued, transcripts of students' grades are of limited use to admissions officers because the kind of grades that are given can vary dramatically from one institution to the next. ${ }^{7}$

One way policymakers can circumvent assessment misalignments is to consider permitting high school students to submit subject matter exams in lieu of the SAT or ACT for postsecondary admission. Subject matter exams, such as the New York Regents or the Golden State Exams in California, have the advantage of being keyed to the content of specific high school course requirements. Another option is for high schools and colleges to use the SAT II: Subject Tests as one of their standards for college preparation.

Regardless of what specific actions are taken, postsecondary institutions would do well to align their admissions policies and placement exams more closely with key K-12 assessments. Several benefits would likely ensue. Students, for instance, would have a greater stake in doing well on state assessments if they knew these assessments had a meaningful correlation with postsecondary success. And dialogue would be fostered between postsecondary and high school faculties, creating a powerful incentive to reach a consensus on what students need to learn. And more data would be available to use in admissions/placement decisions and for high schools to use for diagnostic purposes (to prepare students).

Students from economically disadvantaged backgrounds are hampered by the confusing signals regarding what they need to know and be able to do for postsecondary success. Such students need counseling early on, starting in the middle school years when academic tracking begins in earnest. If students and their parents are not aware of the sequence of courses that must be taken for postsecondary admission, they are likely to discover all too late that they have missed out on certain "core" courses. Hayward told the conference audience that ability tracking, which may start as early as grade four, has a powerful influence on later course-taking patterns.

Better counseling also can rectify the lack of information students have regarding the postsecondary application process. Hayward said that about six percent of otherwise quali- fied high school students fail to take all the tests required for postsecondary admission. Other students wrongly think that a postsecondary education is simply unaffordable. Such students need guidance on everything from selecting an appropriate two- or four-year institution to applying for financial aid.

Postsecondary outreach programs can play a central role in assisting high school students. Too many of these programs, however, have had such poor evaluation designs that it is impossible to know just how successful they have been in reaching traditionally under-served students. ${ }^{8}$ Clearly, outreach programs need to be better assessed for both quality and cost-effectiveness.

Overall, parents, educators, and policymakers have too little information as to how students from specific high schools fare in postsecondary institutions in terms of remediation and drop-out rates. While some states do send reports on the percentages of students who fail placement tests to each high school, these reports are rarely revealed to the public or discussed by local educators. In California, for instance, postsecondary institutions send "grade discrepancy reports" to high schools informing them of students whose performance has not matched expectations based on high school grades, but these reports do not always have the intended effects.

States should consider developing a centralized K-16 data reporting system that would allow policymakers, educators, and the mass media to trace the progress of students from high schools through postsecondary institutions. As a result, remediation and graduation rates would be well publicized. Such a system would reveal the areas in which high school academic standards and postsecondary expectations are significantly misaligned. It would also "unmask" high schools in which rampant grade inflation disguises inadequate teaching and a less than rigorous curriculum, and colleges whose admission standards are too low and whose remedial efforts are ineffective.

\section{Shortcomings and Misalignments in K-16 Teaching}

Ever since it was published in 1964, the Coleman Report has cast a long shadow over efforts at education reform. By suggesting that educational achievement was inextricably linked to students' socioeconomic status, the report appeared to render almost superfluous attempts to raise student achievement by improving classroom teaching in schools serving poor, 
minority students. At the "Education Reform into the Millennium" conference, however, Kati Haycock, Director of The Education Trust, and Linda Darling-Hammond, Executive Director of the National Commission on Teaching \& America's Future and Professor of teaching and learning at Stanford University, called attention to research demonstrating that teachers have marked effects on students' academic success. A Tennessee study conducted by William Sanders, for instance, has discovered that low-achieving students taught by the least effective teachers made gains of only 14 percentile points during the school year; similar groups of low-achieving students, however, made gains of 53 percentile points when taught by high achieving teachers. ${ }^{9}$ Additionally, Ronald Ferguson, the author of an influential study of 900 school districts in Texas, found that teachers' expertise accounted for 40 percent of the variance in students' reading and math achievement at various grade levels. ${ }^{10}$

The fact that skillful teaching can indeed make a profound difference in achievement levels is good news. Also encouraging is the large number of states now beginning to address teacher quality issues. At least 20 states have raised their standards for teacher licensure, and another dozen states or more are developing comprehensive approaches to improving teacher quality. The bad news, as detailed by Haycock at the conference, is that far too many teachers still have an insufficient grasp of the subjects they teach, especially those working in schools serving the poorest, neediest students. Such inadequately prepared teachers will be unable to close the achievement gaps between White, African-American, and Latino students - gaps that are once again widening after having narrowed between 1970 and 1988. And such teachers will certainly not be capable of helping students master more demanding academic standards when they themselves have but tentative command of the subject matter required to demonstrate mastery. Students routinely subjected to poor teaching attend postsecondary institutions at much lower rates, and those who do attend are far less likely to return for their sophomore year. ${ }^{11}$

Before the quality of classroom teaching can be improved significantly and aligned to more rigorous K-16 standards, issues related to the insufficient supply, distribution, and retention of high-quality must be addressed.

In her conference presentation, Haycock asserted, "Too many teachers just don't know their subjects well enough. They'll turn to us with tears in their eyes and say, 'How can I help my students meet these standards?" The problem, Haycock said, was that states had raised their standards for K-12 stu- dents but not for teachers or for the institutions that prepare them.

While every district seeks high-quality teachers, many districts - especially high-poverty urban districts—are finding it increasingly difficult to recruit them on account of high demand coupled with high attrition rates. A looming teacher shortage is likely to make things worse. The American Council on Education estimates that 2.5 million new teachers will be needed by the year 2010, with particularly severe shortages in the fields of math and science. ${ }^{12}$ Urban school districts with disadvantaged populations have sometimes been compelled to respond to shortages by hiring large numbers of less than fully qualified teachers. In the Los Angeles Public Schools, for instance, 18 percent of all teachers are teaching on "emergency credentials," which means that they have not completed-or in some cases even begun-their teacher preparation coursework..$^{13}$ Other school districts and states with large poor and minority populations also rely on high numbers of inadequately credentialed or skilled teachers. In Texas, for example, African-American and Latino children are far more likely than Whites to be taught by teachers who scored poorly on the Examination for the Certification of Educators in Texas (ExCET) — a test of teachers' basic skills and knowledge.

Of course, the mere fact that a teacher holds a state license does not necessarily mean that he or she is adequately prepared. Stephen Clements, Assistant Professor of educational policy studies at the University of Kentucky, who has closely studied the effects of Kentucky's school reforms, told the conference audience that Kentucky's high national ratings in terms of teachers holding master's degrees and full credentials may mislead policymakers. The problem is that such measurements gauge inputs rather than outputs and do not necessarily reflect the kind or quality of courses teachers have taken. A study of Kentucky middle school teachers' college transcripts, for instance, reveals that only 39 percent of the state's middle school math teachers had majored or minored in math. And the performance of recent teacher education graduates on subject area competency tests varies across the states, suggesting weaknesses or unevenness in the teacher preparation system of some states.

In all too many American classrooms, credentialed teachers- that is, teachers with bachelor's degrees who have completed certified teacher preparation programs — are teaching a subject in which they do not have an academic major. In fact, out-of-field teaching has been termed the hidden crisis in American education by researchers such as Richard 
Ingersoll, who has studied the issue for the U.S. Department of Education. ${ }^{14}$ In California, only 51 percent of secondary teachers hold a degree in the field they teach; in Louisiana, only 50 percent have such a degree. Nationally, more than 50 percent of classes in high-poverty schools are taught by teachers lacking a major in their field; in low-poverty schools, less than 15 percent lack a major. ${ }^{15}$

Furthermore, teachers earn certification from hundreds of schools of education, which are highly uneven in terms of the quality of their programs and the standards prospective teachers are expected to meet. Some teacher preparation programs, for instance, are not well-aligned with new K-12 academic standards; prospective teachers are too often acquiring outmoded or insufficient subject matter knowledge, as indicated by high failure rates on teacher tests given in such states as Texas and Massachusetts.

Recruitment of qualified candidates is also a problem for some districts. While some affluent school districts may have as many as 100 applicants for each opening, poor urban and rural districts consistently have difficulty attracting qualified candidates. Lower salaries are one obvious reason for this problem as are poor working conditions that may include dilapidated facilities, inadequate classroom supplies, and unstable teaching and administrative staffs.

Nevertheless, many urban school districts have compounded their recruiting difficulties with highly bureaucratic and inefficient hiring practices. In Oakland, California, for instance, where long-term substitutes often serve for months in understaffed schools, reports abound of qualified candidates so frustrated with cumbersome hiring practices that they have given up and gone on to teach in other districts. Before the enactment of recent reforms, candidates in New York City reported similar experiences, often finding themselves being shuffled from one administrative bureau to the next.

As John Merrow, host of Public Broadcasting Service's television series The Merrow Report, has argued, teacher attrition may be an even bigger problem than teacher recruitment. If we recruit new teachers but fail to retain them, our recruiting efforts will have little lasting impact. In some distressed urban districts, an estimated 50 percent of the teaching force leaves every five years.

Unsatisfactory working conditions are undoubtedly a key cause of high teacher turnover. As Merrow has written, shortages generally exist on account of "self-inflicted wounds."16 In most schools, new teachers are given the most challenging teaching assignments. And although things are slowly improving in some schools, the majority of teachers still work in isolation, having little time to engage in dialogue with supportive colleagues. Indeed, induction programs for new teachers are weak or non-existent in most districts. This means that new teachers still all too often face a sink-or-swim situation; they either acquire some confidence and grasp of the craft or disappear altogether from the teaching profession.

As Tom Corcoran, Co-Director of CPRE, discussed at the Fall 1999 conference, professional development in most American schools tends to consist of periodic inservice days during which various "hot topics"-e.g., AIDS awareness, substance abuse, school violence - are presented, usually in no apparent relationship with one another. These topics are infrequently connected to the subject matter teachers are expected to teach, and rarely is there follow-up to help teachers put new knowledge and skills into practice. Consequently, most professional development, as it is currently constructed, does little to help teachers teach to more rigorous standards. Nor is most professional development, which rarely undergoes thorough evaluation, highly regarded by parents and teachers. Parents often see it as a rather problematic "teacher's day off," while teachers too often characterize it as largely irrelevant to their needs. Corcoran argued that we not only need to invest more in professional development but also we need to ensure that the investments support highquality sustained support that is related to the curricula teachers teach.

\section{Moving Tow ard a K-16 System: Improving Teaching}

To improve teaching and move to a K-16 system of education, "Education Reform into the Millennium" conference partners suggested the following strategies:

\section{Develop standards for teachers that are linked to stan- dards for students.}

As pointed out in a recent summary by the Center for the Study of Teaching and Policy, states have been extremely active adopting standards for students but slow to adopt them for teaching. ${ }^{17}$ But recently, legislators and policymakers have begun to realize that if what teachers are being taught is not aligned with K-12 standards, they will find it extremely difficult to help students achieve at higher levels.

This concern with what teachers actually know and can therefore teach is resulting in a heightened focus on the college education that teachers are receiving. Should all teachers be 
required to attain an academic major in the subjects they plan to teach? Exactly what is being taught in schools of education? Are the arts and science courses well-aligned with the needs of prospective teachers? And, perhaps most important, how can colleges and universities be held accountable for the teachers they produce?

States are beginning to answer these questions in different ways. Several states are likely to follow the Wisconsin and Minnesota examples of requiring teachers to major in the subject they plan to teach, complete teacher preparation coursework, and undergo lengthy student-teaching internships supervised by a cooperating teacher. Others, like Georgia, have created new K-16 committees charged with establishing standards for teacher preparation that are aligned with $\mathrm{K}-12$ standards. Connecticut has combined a more rigorous licensing process with strong supports for new teachers. A number of other states, such as Massachusetts and Texas, are using more rigorous certification exams to hold education schools accountable. In Massachusetts, high failure rates have produced concerns regarding the quality of teacher preparation. In Texas, schools of education whose teachers score less than 70 percent on the state licensing exam will lose the right to prepare teachers.

\section{Develop new linkages between education school fac- ulty and arts and science faculty.}

College presidents and policymakers alike are beginning to realize that the arts and science faculty - as well as the education faculty - must take responsibility for teacher preparation if students are to arrive at their institutions fully prepared. As Harold Hodgkinson has noted, "No faculty member in higher education ever got tenure because of a concern for the linkage of higher education with "lower education." 18 Indeed, most arts and science faculty have operated completely within their own sphere, uninterested not only in K-12 education but also in how education school faculty on their own campuses prepare undergraduates hoping to become teachers.

But change is beginning to occur on a number of campuses. For instance, at the University of Texas at El Paso and Eastern Connecticut University, education and arts and sciences faculties regularly collaborate on what and how future teachers should learn. And Northeastern University in Boston is in the process of becoming the nation's first school of education run by faculty members primarily from outside the education department. Arts and sciences professors will choose the curriculum, make hiring and tenure decisions, and conduct research. The goal is to make subject matter prepara- tion in core subjects like English, science, and mathematics central to a teacher's preparation.

\section{Improve teacher recruitment, especially in under- served school districts and subject areas.}

Paying higher salaries is the most obvious way to attract teachers to schools and school districts that have had difficulties attracting high-quality candidates. But constraint on funding, combined with a traditional reluctance on the part of school boards and unions to offer differential pay, makes this difficult to do. However, some school districts, like Houston and Philadelpia, are offering new teachers signing bonuses, while some states, like North Carolina, are offering four-year college scholarships to students who commit to teaching in state schools for at least four years. Some states also are offering incentives to teach in certain high-need subject areas. California, for instance, offers a loan forgiveness program for prospective math teachers and awards grants to current teachers so they can pursue math credentials.

School districts also can eliminate much of the red tape teaching candidates have had to endure. In 1997, New York City began forming partnerships with local universities and streamlining many of its hiring practices. Consequently, the city, once flooded with uncredentialed teachers, is now filling almost all its vacancies with well-qualified teachers. Older workers considering a career change can also be an important source of new teachers. A number of universities, businesses, and school districts have developed programs for people wanting to make a mid-career change into teaching. New York City is now considering offering its own training program to lure these people into teaching.

\section{Better mentoring and support for new teachers.}

State legislatures and school districts, increasingly aware of the isolation and stress faced by new teachers, are taking steps to ensure that beginning teachers get better support. In school districts such as Rochester, New York, for example, new teachers are assigned to work with experienced veterans with whom they frequently meet and consult. In other districts, such as Toledo and Columbus, Ohio, peer review programs serve the dual function of both assisting and evaluating new teachers, even counseling some people out of the profession.

Such changes in long-standing but poorly conceived practices pertaining to new teachers also would make a big difference in improving professional practice and diminishing teacher attrition. Instead of routinely giving new teachers the 
most difficult teaching assignments, for example, they could be given diminished teaching loads.

\section{Rethink and improve professional development.}

Corcoran and others have argued that professional development should be about "the continuous improvement of professional practice." This would require a dramatic shift away from the widespread notion of professional development as a series of unrelated events and workshops provided by "experts." Instead, Corcoran said at the Fall 1999 conference, professional development would be ongoing and thorough, providing "educators opportunities to become more intellectually engaged with their profession and disciplines." The sharing of craft knowledge and the deepening of subject matter understanding - and not the dispensing of information and techniques — would become the focal points.

Three components are central to this vision of professional development. First, schools and districts would have to provide time, support, and incentives for professional development to be embedded in the work of teachers. Second, teachers would have to take substantial responsibility for their own professional growth within the context of daily school life, trying new approaches in the classroom, reflecting upon practice, and making collaborative decisions about how concepts should be taught. Third, professional development should be first and foremost centered on the curriculum to be taught and how children master it. District 2 in New York City, for example, dramatically raised its students' reading scores by centering its professional development on literacy instruction.

Implementing this kind of professional development requires that teachers have more time for reflection and collaboration, which is not easy to provide. Efforts to reduce teacher workloads or to lengthen the school year are likely to meet opposition on both political and economic grounds. However, funds currently being spent on professional development could be reallocated. Instead of spending money on in-service days and less relevant college courses, funds could be targeted to support professional development schools, teacher networks, study groups, and summer institutes.

A great deal is known about the kind of professional development that leads to improved practice. While there is not one best system, effective professional development offers teachers opportunities to deepen their knowledge of the subject matter they teach, the ways in which students understand and misunderstand the subject matter, and the best strategies to engage students in mastering it. Effective profes- sional development also offers follow-up support in the form of coaching or collegial work groups that encourage teachers to reflect on their practice and get feedback from their peers. It uses student work to draw teachers' attention to what students understand and what they don't and to the instruction that produced the result. Good professional development, then, is embedded in the work of teaching. It is ongoing and serious.

\section{Conclusion: Why Focus on K-16 Coordination?}

The upsurge of interest in a K-16 system has come from two different directions. From one direction, there is heightened awareness that teachers, parents, and students need a deep and early understanding of what a postsecondary education requires, both in an academic and a procedural sense. Of course, understanding is not enough. Students, especially those from economically disadvantaged backgrounds, must also attend good K-12 schools with high-quality teachers - teachers whose own deep grasp of the subjects they teach enables them to help students acquire the skills and knowledge that postsecondary education requires.

From the other direction is the realization on the part of postsecondary institutions that they have strong incentives, both social and academic, to collaborate with K-12 education. Only by doing what they can to assure the quality of teachers and schools - participating in the establishment of academic standards, preparing teachers with rigor, relaying clear signals as to what their institutions require - can they reduce remediation and drop-out rates and, more importantly, give students from all backgrounds an opportunity to attend and graduate from their institutions.

Advocates of a more coherent K-16 system face a variety of obstacles. As noted earlier, the K-12 and higher educational systems have operated largely independently for over a century. Postsecondary faculties have rarely involved themselves - or have been invited to involve themselves - in K12 affairs. Furthermore, liberal arts faculties have rarely worked with the education schools' faculties within their own colleges and universities, too often blaming education faculties for poor scholarship and inadequate preparation of future teachers. Clearly, arts and science faculties need to accept greater responsibility for the preparation of teachers.

Finally, many political divisions must be overcome for a unified K-16 vision to emerge. As an Indiana state representative complained at the conference, "Schism is the norm" in 
how legislators have approached education issues, often dividing themselves into K-12 and postsecondary contingents.

Nevertheless, the fact that over a dozen states as well as numerous communities are now developing K-16 plans suggests that a corner has been turned. Georgia's regional K-16 councils, the K-16 collaboration between colleges and schools in El Paso, Texas, and the many K-16 exploratory committees in other states, suggest that cooperation between traditionally competing segments of the education system just may over time become the rule rather than the exception. It is none too early.

\section{End Notes}

1. Usdan, M., Minar, D., and Horowitz D., Education and State Politics: The Developing Relationship Between Elementary-Secondary and Higher Education (New York, NY: Teachers College Press, 1969).

2. Hodgkinson, H., All One System (Washington, D.C.: Institute for Educational Leadership, 1985).

3. The Education Trust, conference overhead (1998).

4. National Center for Educational Statistics, Digest of Educational Statistics, 1995 (Washington, D.C.: U.S. Department of Education, 1995).

5. Office of the Chancellor, California State University, Long Beach, California. In 1999, California State University reported that 68 percent of their freshman entering from high school needed remediation.

6. David Conley to "Education Reform into the Millennium" conference participants, memorandum, September 28, 1999.

7. Kirst, M.W., "Bridging the Remediation Gap," Education Week (Volume 18, Number 1, September 9, 1998, pp. 52, 76).

8. Tierney, W. "Continuing Tales: Evaluation of College Outreach Programs." Presentation at the College Board Conference, San Diego, CA, 2000.

9 Haycock, K., “Good Teaching Matters," Thinking K-12 (Summer 1998).

10. Ibid.
11. Overheads from K. Haycock's presentation at the "Education Reform into the Millennium" conference.

12. American Council on Education, To Touch the Future: Transforming the Way Teachers are Taught (Washington, D.C.: Author, 1999).

13. California Commission on Teacher Credentialing, 1999.

14. Ingersoll, R., "The Problem of Out-of-Field Teaching," Kappan (Volume 79, Number 10, June 1998, pp. 773-776).

15. Ibid.

16. Merrow, J., "The Teacher Shortage: Wrong Diagnosis, Phony Cures," Education Week (Volume 19, Number 6, October 6, 1999, pp. 48, 64).

17. Hirsch, E., Koppich, J.E., and Knapp, M.S., "What States Are Doing to Improve the Quality of Teaching." CTP Working Paper (Seattle, WA: Center for the Study of Teaching and Policy, 1998).

18. Hodgkinson, H.L., All One System: A Second Look (Washington, D.C.: Institute for Educational Leadership, 1999).

\section{Research Reports from the National Research and Development Centers}

Need more research? Visit a new web site that links more than 600 reports from the 12 national $R \& D$ centers. The site can be accessed at research.cse.ucla.edu. Funded by the Office of Educational Research and Improvement, many centers conduct research that crosses specific education topics.

The new site is a joint product of the Organization of Research Centers communicators. 


\section{Recent CPRE Publications}

\section{District Leaders' Perceptions of Teacher Learning}

James Spillane

February 2000 (No. OP-05) 31 pp., \$4

Examines district leaders' theories about teacher learning and change, identifying and elaborating three perspectives based on a study of nine school districts.

Improving State School Finance Systems: New Realities Create Need to Re-Engineer School Finance Structures Allan Odden

February 1999 (No. OP-04) 43 pp., \$6

Explores the inadequacies of state school finance systems and recommends short-term changes that states can make to their funding structures in order to accommodate more fundamental and long-term changes.

\section{Instruction, Capacity, and Improvement}

David Cohen and Deborah Loewenberg Ball

June 1999 (No. RR-043) 41 pp., \$10

Develops a theoretical view of instruction and then provides an analysis of the environments of instruction. Concludes with a discussion of the problems and possibilities for intervention.

\section{School-Based Performance Award Programs, Teacher Motivation, and School Performance: Findings from a Study} of Three Programs

Carolyn Kelley, Herbert Heneman III, and Anthony Milanowski

April 2000 (No. RR-044) 71 pp., \$10

Focuses on teachers' motivational reactions to school-based performance award programs, the degree to which teachers' motivational reactions are related to school performance, and principals' assessments of the effects of the programs.

\section{When Accountability Knocks, Will Anyone Answer?}

Charles Abelmann and Richard Elmore, with Johanna Even, Susan Kenyon, and Joanne Marshall March 1999 (No. RR-042) 51 pp., \$10

Presents a working theory of school-site accountability among three factors: responsibility, expectations, and internal and external accountability. Short case studies of a diverse sample of schools are included.

To order, write: CPRE Publications, 3440 Market Street, Suite 560, Philadelphia PA 19104-3325. Prices include handling and book-rate postage (Add \$10 shipping and handling for delivery outside the U.S.). Sales tax is not applicable. For information on quantity discounts (over 25 copies), call 215/573-0700, ext. 233. Sorry, we cannot accept returns, credit card orders, or purchase orders. All orders must be prepaid with U.S. funds from U.S. banks; make checks payable to CPRE/Trustees of the University of Pennsylvania. Please allow 2-3 weeks for delivery. 


\section{About CPRE}

The Consortium for Policy Research in Education (CPRE) unites five of the nation's leading research institutions to improve elementary and secondary education through research on policy, finance, school reform, and school governance. Members of CPRE are the University of Pennsylvania, Harvard University, Stanford University, the University of Michigan, and the University of Wisconsin-Madison.

CPRE conducts research on issues such as:

- education reform

- student and teacher standards

- state and local policymaking

- education governance

- school finance

- teacher compensation

- student incentives

To learn more about CPRE or CPRE publications, please call 215/573-0700.

\section{Nondiscrimination Statement}

The University of Pennsylvania values diversity and seeks talented students, faculty, and staff from diverse backgrounds. The University of Pennsylvania does not discriminate on the basis of race, sex, sexual orientation, religion, color, national or ethnic origin, age, disability, or status as a Vietnam Era Veteran or disabled veteran in the administration of educational policies, programs, or activities; admissions policies, scholarships, or loan awards; and athletic or University administered programs or employment. Questions or complaints regarding this policy should be directed to Executive Director, Office of Affirmative Action, 1133 Blockley Hall, Philadelphia, PA 19104-6021 or (215) 898-6993 (Voice) or (215) 898-7803 (TDD).

\footnotetext{
World Wide Web:

www.upenn.edu/gse/cpre/

www.wcer.wisc.edu/cpre/
}

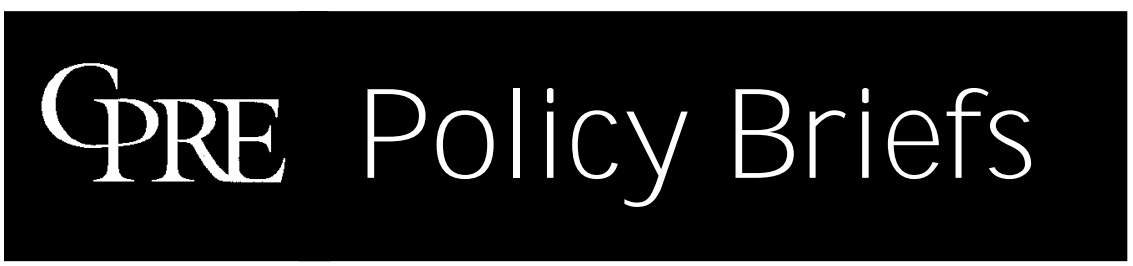

NON PRO FIT

U.S. POSTAGE

PAID

PERM IT N O . 2563

PHILADELPHIA, PA

Graduate School of Education

University of Pennsylvania

3440 Market Street, Suite 560

Philadelphia, PA 19104-3325 